\title{
Identity Issues in Syrian Diasporic Realities: An Autoethnographic Interpretation
}

\author{
Ghada Alatrash \\ University of Calgary \\ galatrash@mtroyal.ca
}

\begin{abstract}
This article, part of a larger study, seeks to understand the lived experiences, human conditions and identity issues of families in the Syrian Diaspora in Canada. To do so, I engage with autoethnography as a research methodology and a method. I reflexively write from my own personal experiences as a Syrian immigrant in order to better understand the Syrian refugees' human experiences. My research participants were three Syrian refugee families in Calgary. As I autoethnographically analyzed, presented, and interpreted the stories of the three families, I identified a number of themes (Alatrash, 2019). I discuss some of them in this paper: "On cultural identity," "On negotiating difference," and "On the fact of difference-Orientalism and beyond."
\end{abstract}

Keywords: Syrian refugees; autoethnography; Diasporic realities; cultural identity

\section{Introduction}

The Syrian Diaspora is a complex topic that speaks to issues of dislocation, displacement, loss, exile, identity, resilience and a desire for belonging. My research seeks to better understand these issues through the lived experiences and human conditions of Syrians living in the diaspora in Canada. To do so, I explore the central question: How do Syrian newcomers come to make sense of what it means to have lost a home and a homeland as it relates to their diasporic experiences? In my study, I broach the Syrian diasporic subject by thinking through an antiOrientalist, anti-colonial framework.

I engage autoethnography as a research methodology and a method, "an approach to research and writing that seeks to describe and systematically analyze (graphy) personal experience (auto) in order to understand cultural experience (ethno)" (Carolyn Ellis, Adams, \& Bochner, 2011, para. 1). Accordingly, I reflexively write from my own personal experiences as a Syrian immigrant, so that I can better understand the Syrian refugee's human experiences in Canada. As part of my doctoral research (Alatrash, 2019), I conducted three open-ended, unstructured, interactive interviews in which I engaged with my participants' voices and their stories in order to co-construct knowledge on my research topic. My research participants were three Syrian refugee families living in Calgary, Alberta. The interviews conducted with the adults in each family were held in Arabic, and afterwards, I translated and transcribed them into English.

As I analyzed, presented, and interpreted the stories of the three Syrian families, and as we considered the meanings and feelings of the lived experiences of the Syrian Diasporic realities in Canada, one theme that surfaced consistently across our conversations spoke to issues 
of identity, explicitly and implicitly. This essay presents a summary of three findings that emerged: firstly, "On cultural identity"; secondly, "On negotiating difference"; thirdly, "On the fact of difference-Orientalism and beyond." (A detailed explanation of the research and analysis of findings is presented in my doctoral thesis (Alatrash, 2019).

\section{On Autoethnography}

As mentioned earlier, I employed autoethnography as a lens through which I engaged and analyzed my personal lived experience as a Syrian immigrant who holds the same Syrian passport as a refugee (albeit, under considerably different lived experiences) in order to better understand the Syrian refugees' lived experiences. In other words, as I sought to understand the Syrian Diasporic experiences, I employed my personal connections with the topic, as well as my lived experience as a Syrian immigrant, as a "springboard" (Chang, 2008, p. 66) to my research. Heewon Chang (2008) suggests that autoethnographic research is a medium that may be engaged to arrive at what Max Weber refers to as a cultural "verstehen" or, as she explains, an empathetic cultural understanding of others. I deliberately engaged with the notion of a "cultural verstehen of others." I reflected on how it can become an important tool in a process of "crosscultural pollination" (Chang, 2008, pp. 27-29) between the Syrian newcomers and Canadian hosts. My goal in this essay is to explicate a "cultural verstehen" of the Syrian refugee experiences. As suggested by Chang (2008), I plan to turn the "former others of difference into others of similarity by reducing strangeness in others and expanding their cultural boundaries" where this "transformational process... [of] cross-cultural pollination affects both parties" (p. 29). Carolyn Ellis et al. (2011) concur and speak of an empathetic understanding evoked by autoethnography. They explain that many scholars turn to autoethnography because:

they wanted to concentrate on ways of producing meaningful, accessible, and evocative research grounded in personal experience, research that would sensitize readers to issues of identity politics, to experiences shrouded in silence, and to forms of representation that deepen our capacity to empathize with people who are different from us. (para. 3)

Furthermore, Gramsci (1971) writes: "the starting-point of critical elaboration is the consciousness of what one really is, and is 'knowing thyself' as a product of the historical processes to date which has deposited in you an infinity of traces without leaving an inventory" (p. 324). Autoethnography then became a vehicle that I engaged to journey into my personal history in order to make sense of my present lived experience, as well as the experiences of the research participants.

\section{Research Participants}

To ensure that my research engaged a heterogeneous representation of the peoples of the Syrian Diaspora, my interviewees included three Syrian families (husbands and wives - all parents) with a diversity in religious and ethnic backgrounds (namely, a Syrian-Christian family, a Syrian-Shiite-Druze family, and a Syrian-Sunni-Muslim family). They were also diverse in their educational and socio-economic backgrounds, political affiliations (pro or anti-Syrian regime), as well as in their immigration sponsorship (private or government). The following is an overview of my participants. All names used are pseudonyms. 


\section{Family 1}

Antoine and Mary - a husband and a wife in their mid-forties with one child. They are a Syrian-Christian family and are privately sponsored refugees by a local church in Calgary. They both hold university degrees from Damascus University in Syria. Their immediate families remain in Syria to this day. Their interview was held on October 12, 2017 in their home in Calgary.

\section{Family 2}

Daniel and Miral - a husband and a wife in their late-twenties with one child. They are a Syrian-Shiite-Druze family, privately sponsored refugees by a Canadian Group of Five (G5). They arrived from Lebanon after having fled a war-torn Syria. Daniel holds a two-yearcertificate in a business related field. Miral holds a university degree in Education. Daniel's brother lives in Canada while Miral's immediate family remains in Syria. Their interview was held on October 13, 2017 in their home in Calgary.

\section{Family 3}

Adam and Brianna - a husband and wife in their mid-forties with five children. They are a Syrian-Sunni-Muslim family sponsored as Government Assisted Refugees (GAR). They arrived from a refugee camp in Jordan. Their home in Syria was destroyed in the war. Adam owned his own small business in Syria. Brianna was a housewife and holds a high school certificate. Their interview was held on December 10, 2017 in their home in Calgary.

\section{Myself as an Autoethnographer}

In my research, I became a "participant observer" (Carolyn Ellis, 2004, para. 6; Lichtman, 2010, pp. 168-170). As a participant observer, my analysis of the stories first took place while observing and interviewing the research participants. Then, as I thought through their conversations, I recognized the raw emotions and dormant memories that the interviews awakened in me. I wrote these moments in an attempt to "describe the conscious experience of both subject [the three families of the Syrian Diaspora] and researcher [myself]" (C. Ellis, 1991, p. 30).

\section{On Cultural Identity}

\section{Looking for Resemblances and Avoiding Differences}

Antoine says, "a homeland is one's character; it's when one can say: I am Syrian [anā $s \bar{u} r \bar{l}]$...I am my homeland." Syria, to Antoine, is his personal and cultural identity. This also hold

true for me; Syria similarly occupies a major part of my cultural identity. Hall (1994) explains,

[C]ultural identity is not a mere phantasm either. It is something - not a mere trick of the imagination. It has its histories - and histories have their real, material and symbolic effects. The past continues to speak to us... Cultural identities are the points of identification... Not an essence but a positioning. (p. 395) 
Indeed, although incommensurable and boundless like a phantasm, my cultural identity is by no means an imagined characteristic. It is the place in which I position myself as a Syrian and as a Canadian, depending on the context of representation, and for me, it has been a notion underpinned with the idea of fluidity and continuity. My identity is constructed through historical moments that find their way into my present life; it is continuously emerging and transforming through lived experiences.

As a woman in her mid-forties, Mary narrates her struggle of "adapting and starting all over, and of trusting anew, and of loving anew, and of getting to know anew, and of opening up anew." She further explains that it is only natural for a human being to choose to be in a space that is familiar and comfortable and one that "resembles" his/her own identity. Mary is exhausted and her spirit is worn out; so she looks for a conversation, for a relationship, where she does not feel the need to have to explain herself. When speaking to a Canadian national who neither comes from Syria nor shares her native language, Mary explains that her conversation is very limited, "Hi. How are you?' ...And then you begin to consider the third sentence that you want to articulate and think about whether or not it is appropriate; you ask, is it suitable, will she [or he] understand it in the way I express it?"

I understood Mary. Isn't the "third sentence” awkward for any two strangers even when they share a common language and culture? How about when we consider that between Mary and her Canadian neighbor exists a gap made up of incommensurable years of history and of culture and traditions, years that have brought their cultural identities into different spaces of identification?

Here, I turn to Stuart Hall again, to try and understand Mary's complex search for something that "resembles" her identity. Hall (1994) suggests that there are two ways of thinking about cultural identity,

The first position defines 'cultural identity' in terms of one shared culture, a sort of collective 'one true self' ... one people', with stable, unchanging and continuous frames of reference and meaning... [The] second position recognizes that, as well as the many points of similarity, there are also critical points of deep and significant difference which constitute 'what we really are'; or rather - since history has intervened - 'what we have become'... [where] difference, therefore, persists - in alongside continuity. (pp. 223-225)

It is in Hall's second definition that I find a space for new possibilities to emerge, where difference, or non-resemblance, may exist without hindering/delaying the process of continuity. However, before we consider this notion of continuity, I would like to reflect deeper on Mary's words. As mentioned earlier, Mary is tired. Her words reflect an exhausted spirit, a spirit was not looking for change or newness, and lacks the drive to speak a "third sentence."

As a refugee, Mary was forced into her new circumstances and came to find herself in a place in which more differences exist for her. It is indeed "unsettling" (Hall, 1994, p. 226) for Mary, and it is problematic. She no longer feels a "oneness" with her surroundings. She no longer "resembles" (in her words) her surroundings, and her surroundings no longer resemble her. The weight of this "difference" is incommensurably heavy and is weighing down her spirit. Difference positions Mary, and her cultural identity, in a state of imbalance. Mary tells her husband, "I don't feel balanced [in Canada]" whereas in Syria, despite the war, as she walked the 
grounds of her homeland, Mary "knew where each step was going to be placed" even as she was aware that "in the next step a shell might approach" and kill her. Yet, as she explains, she was not afraid and walked "solid steps" on a land she knew "inch by inch."

Mary felt grounded in her past, in her history, and in her homeland. In contrast, she describes her presence in Canada as a feeling of "weightlessness," like that of an "astronaut... floating in space...unable to walk on the ground and is looking for anything to hold onto." She says, "this is how I felt; that I needed anything to hold onto."

In this conversation, Antoine engages the Arabic word "hayūlā" to describe Mary's feeling. The word was new to me. Although I could have resorted to a dictionary to translate this word, I did not. This was my opportunity to give Antoine and Mary pedagogic agency through the notion of difference, a difference that was situated in their native linguistic and cultural funds of knowledge (Moll, Amanti, Neff, \& Gonzales, 1992). Antoine repeated the word in Arabic as if it were obvious to understand. I still did not recognize the Arabic word and I felt the effect of this deficiency in my knowledge-I was not embarrassed but relieved. I happily and explicitly shifted into a position of a learner and gave way to valuable knowledge that was available to my research participant through difference. Mary and Antoine explained that the Arabic word-alhay $\bar{u} \bar{a}$ - refers to a primordial state of being, and within the context of our conversation, it depicted their feeling of spiritless-ness as a result of having left behind their spirits in their homeland. They expressed that they felt as if they had regressed to a primordial state of being.

Antoine then resorted to the word "bewilderment" to further clarify their feelings. I thought about the word bewilderment. It is a word indeed steeped in lived experiences. I thought about language, whether and when Antoine might have learned this word in English-was it before he arrived in Canada, or did he look up the English translation of hayūla as a result of needing to articulate his thoughts and express his emotions to a Canadian?

I thought of my father and of his decision to immigrate in 1986 to the United States of America. My father chose to immigrate because of my brothers and I. He had accepted an invitation to teach at a local university in Abilene, Texas, upon his arrival to the U.S. As I thought of my father, I wished I could have asked him about his experiential knowledge as an immigrant. (I am mindful here of the fact that my father was an immigrant and not a refugee). I wished I had asked him, whether or not he had felt a sense of weightlessness when he first arrived in Abilene (as a man in his 60s), and furthermore, how he might have dealt with similar immigrant lived experiences? I wished I could have asked him, "Baba [Daddy] what did you hold onto?"

I wrote a fictitious story about $A b u$ [father of] Maryam and $U m$ [mother of] Maryam (Alatrash, 2016), a husband and a wife who were forced by the war to leave Aleppo, Syria, and to seek refuge in Houston, Texas, where their daughter lives. When I wrote this story, I was thinking of my father. I thought of him and how of he spent his last years of life in small town, Abilene, Texas. As I tried to make meaning of his experience, I wrote: "To leave a homeland was to leave a piece of one's heart and soul behind" (Alatrash, 2016, p. 126). I vividly recall how, after leaving Syria, my father was never whole again. 


\section{On the Differences between Immigrants and Refugees}

Miral speaks of what it means to have lost a homeland. She believes that "the experience of every immigrant is in what he has lost... Because a homeland is what has deposited in us all the pieces that make us up today in our current state." She too believes that to have lost a homeland is to have lost a piece of one's soul, a side of one's character; she describes this as an experience of "losing something that had been deposited in your soul."

Perhaps baba (my father) did not feel a state of hayūlā, for, as Mary explains, unlike a refugee, an immigrant is "thoroughly prepared...expecting" what is awaiting him/her; that things are "much easier" for an immigrant, whereas as for a refugee, "you feel like you have been yanked, yanked from your land and placed on another land, and as you are already in an unbalanced state, you will definitely come to find it difficult... The idea is that you have taken me to a ground that I have not treaded before." Yan and Anucha (2017) write,

...most of the global stock of migrants are forced to leave (or to flee) their home country because of natural catastrophe (e.g., famines or flooding) or human-made disasters (e.g., wars and political persecution). These migrants are called refugees. Most of the time, their departure from the home country is sudden and involves no well thought out plan or preparation. (pp. 9-10)

In the above passage, I find a number of parallels between Mary's words and Yan and Anucha's. I understood Mary's words. Mary is right-I was not a refugee, nor was my father; our lived experience and human condition (as Syrians) ought to not be compared with hers. Simmons (2012) writes, "Autoethnography...is about understanding the relationship of freedoms and unfreedoms... which come to entangle and envelope what it means to be human through the web of local histories. Ultimately, autoethnography is affirming local ways of understanding the Diasporic experience embodied through personal memories/histories" (p. 33). My father had the freedom to choose to immigrate to the U.S. It was not a forced choice; he spoke English, and had a cousin in Texas awaiting him. He had a university post assigned to him on a work visa prior to arriving. He chose to come so that we, his three children (my two brothers and I), may live the life that we are living today. My point is: my father and mother were prepared to come as immigrants to the U.S., socio-economically, mentally, spiritually, and so forth; the research participants, Antoine and Mary, Adam and Brianna, and Daniel and Miral were not.

As I was reflecting on Mary's thoughts and trying to make meaning of the Diasporic experience, I turned back to Edward Said. The process of interpretation was continuously unfolding. I was moved by the fact that Said (2002) also uses the word bewildered in his definition of refugees. He explains how the word 'refugee' has come to politically suggest "large herds of innocent and bewildered people requiring urgent international assistance" (p. 181, my emphasis). I have come to understand the depth of this word through the state of weightlessness embodied in its meaning. I also noted that Said (2002) as well as Yan and Anucha (2017) refer to refugees as "herds" and "stock." In their conditions as refugees, these disasporic subjects are more often dehumanized. The words "herds" and "stock" are constitutive of a de-humanizing condition. Today, I have come to understand these words on a deeper level. Indeed, the human conditions and the lived experiences of refugees are different than those of immigrants, and in turn, the process of negotiating their new cultural identities ought to be considered as positioned within this complex framework of understanding. 
In summary, for the peoples of the Syrian Diaspora, cultural identity speaks to a deep connection with a homeland, where they feel a oneness with their homelands. Moreover, as they try to negotiate their new identities they look for balance and wholeness. Displaced Syrians search for that which resembles their cultural identities and for the cultural similarities they share with other Syrians. They steer away from cultural differences that position them, as they tell us, in a state of bewilderment, outside-ness and out-of-place-ness (Said, 1999).

\section{On Negotiating Difference}

Hall (1994) speaks of different views of cultural identity, where identity is also about becoming and being. He writes,

[A]s well as the many points of similarity, there are also critical points of deep and significant difference which constitute 'what we really are'; or rather - since history has intervened - 'what we have become'... Cultural identity, in this second sense, is a matter of 'becoming' as well as of 'being'. (p. 394)

Hall (1994) further suggests that cultural identity "belongs to the future as much as to the past," that is it is not fixed in a place, time or history, and that it "undergo[es] constant transformation" (p. 394). He also importantly insists that cultural identity is "far from mere 'recovery' of the past" (p. 394).

I find Hall's suggestions to be very helpful as I try to make meaning and interpret the words and feelings of the families in my research. For example, Adam says, "A homeland stays with you." Miral explains, "But a homeland is the period in your life that cannot be repeated; for me, a homeland is the experience that cannot be relived... it is indeed Syria...Syria that has given me something that cannot be given by any other place." She insists that the past is an experience that cannot be re-lived or re-covered. As for Mary, she speaks of her awareness of the cultural transformation onto which she was bound. Before even setting foot on the plane, she realized that an unavoidable change of the self - the becoming of the identity - is destined to happen. She understood that she could not be fixed in her past, that identity is continuous and emerging, and that when she returns one day, she will return as "a changed person."

How does Mary negotiate her cultural identity alongside the differences, while grounded in the past and living a moment of continuity? How does one balance the absence of an unrecoverable past in a new present surrounding? Can the new also bring balance, not by way of replacing the old, but by situating itself as part of an evolving and transforming cultural identity?

For Miral, the aroma of rain, the shape of her home, the uniqueness of her home, the food and pickled eggplants and cracked wheat - these are all cultural elements that constitute differences for her in a Canadian culture; they are also her ways of knowing and defining her unique Syrian cultural identity. Cabral (1973) writes, "Whatever may be the ideological or idealistic characteristics of cultural expression, culture is an essential element of the history of a people. Culture is, perhaps, the product of this history just as the flower is the product of a plant" (p. 42). Miral says, "culture is the hindrance...to find the similarities...to share a mindset and a way of thinking"; she adds, "I told you that the people and places are not repeatable and this is the hindrance for me." 
The questions become: In what ways could the Syrian Diasporic peoples negotiate difference in their cultural identities and as they are situated in their newfound land of Canada, while keeping in mind that difference is a product of a history underpinned by colonial narratives and hegemonic discourses? How may Syrians come to engage difference alongside continuity as part of their new lived realities? I hope that the following section provides some answers to these questions.

\section{On the Fact of Difference-Orientalism and Beyond}

As an Arab woman wearing the hijab, Brianna is acutely conscious of her body and of her hijab and says, "I felt stares...the stares of people riding the train." She is worried about how people felt about her hijab and whether they "like the hijab or found it strange." She explains that, as a result, she begins to feel embarrassed and does not wish to leave her home. Brianna is living a state of "double-consciousness, this sense of always looking at one's self through the eyes of others" (Du Bois, 2012, para. 4). She identifies herself as "different from them" (emphasis mine). Brianna is conscious of her difference and of her Otherness. She feels uncomfortable in her own body. She is embarrassed. She prefers to stay at home in hiding. However, she explained that her voice of reassurance was her husband's, who continued to tell her that there are many people like her and that she is "no different than them," and that in Canada people do not get into each other's business. Brianna ends this conversation with the words, "And until now, alhamdullilah [Praise be to God], we have not faced any challenges."

I was struck by Brianna's final sentence. I wanted to say, but how then do you classify "the stares?" Are stares not also a form of violation? Is the silence and "non-interaction" not loaded with meaning, and is it not also an act of Othering? Are things truly well and challengefree? In my view, Brianna is Othered. Brianna's feelings of difference, of Otherness, are justified within this context. The silence leaves things unresolved and ambivalent. There is no communication about the significance of the hijab, no understanding exchanged, no empathy engendered. There is only a sense of Othering, a feeling of being Othered, and an acceptance of a reality that is un-acceptingly, and hegemonically, divisive. Hall (1994) writes, "This 'look', from - so to speak - the place of the Other, fixes us, not only in its violence, hostility and aggression, but in the ambivalence of its desire" (p. 233) - a lived experience that seems to fix us in the position of the Other.

As I listened to Brianna, I wanted to shout - no, this is not okay; the stares and the looks are not okay; being Othered is not okay. Indeed, I deeply believe that these are also acts of "violence, hostility and aggression." Borrowing from Frantz Fanon's (2008) notion of "The Fact of Blackness," I also believe that for members of the Syrian Diaspora, and particularly for the Muslim Syrian women wearing the hijab (for not all Syrian women are Muslim nor do all Muslim women wear the hijab), there is a fact of difference. On his experience as a black man in a colonized Africa, Fanon (2008), writes on "The Fact of Blackness":

And then the occasion arose when I had to meet the white man's eyes. An unfamiliar weight burdened me. The real world challenged my claims. In the white world the man of color encounters difficulties in the development of his bodily schema. Consciousness of the body is solely a negating activity. It is a third person consciousness. The body is surrounded by an atmosphere of certain uncertainty. (pp. 85-86)

Cultural and Pedagogical Inquiry, Summer 2020, 12(1), pp. 22-36

ISSN 1916-3460 (C) 2020 University of Alberta

http://ejournals.library.ualberta.ca/index.php/cpi/index 
Fanon, as a black man, and Brianna, as a Syrian Muslim woman wearing the hijab, are both subjugated to acute feelings because of their differences. Their "consciousness" of their bodies in the midst of whiteness or Canadianness is burdening and unsettling. It is Otherizing. It is that feeling of "being dissected under white eyes" (Fanon, 2008, pp. 86-87).

Brianna further shares the severe implications of being Muslim in Canada as contextualized in the lived experience of her ninth-grade son. As Brianna told her story, I sat and felt my heart aching for I too, am a mother of a son in the ninth grade. Brianna narrates the negative experiences that her son experienced in a Calgary school. His Muslim-ness was his fact of difference. He was not only bullied and hit by his schoolmates for praying in public, but as Brianna shares, the young man who hit her son proclaimed, "what has brought you [Brianna's son] to this country; you have to leave; this country is for White people." I felt piercing pain in my heart. It was very difficult and painful to "imagine standing in the shoes" (van Sluys, Lewison, \& Seely Flint, 2006, p. 383) of Brianna and her son.

The implications of hegemonic colonial narratives have found their way into even the minds and ways of thinking of children. Fanon (2008) writes, "I was told to stay within bounds, to go back where I belonged" (pp. 86-87) —indeed, what a painful lived reality to experience. Today, the boundaries remain, and they continue to divide, but I will also continue to insist on a language of hope and of possibilities. How may we come to find solutions for these recurring problems? How do we disrupt a narrative that continues to divide, "encase" (Fanon, 2008, p. 180) and subordinate people as us and them, as Others of difference? How do we undo this fact of difference?

Mary explains that in her experience of living in Canada, she has found that "it is assumed" that everyone coming from the Middle East is "cocooned with her hijab as a female or in his kufiya [a male headdress] as a male." She explains, however, that Syrian Christians, like herself, wear neither hijabs nor kufiyas. As she thinks of the traditional kufiya that none of her family members (or my family members, for that matter) wear, she finds such an assumption comical. She narrates how she was also asked whether there are Christmas trees in Syria. If Syrians have heard of Santa Claus. About how they know how to cook Western food, and whether they eat with their hands. If camels are a mode of transportation in Syria.

Mary also points to the fact that media misrepresentations underpin the West's understandings of the East but, as importantly, she mindfully reminds us that "the West is not only to blame because we [Syrians/Arabs] are also at fault of not representing ourselves in a true way." Edward Said's (1979) Orientalism offers tremendous insight concerning the Western (British French, and later American) production of the "Oriental" subject (the Arab living in Asia, the Middle East, and North Africa). Said (1979) speaks to how "Orientalism" has come to be a mode of discourse that expresses cultural and ideological representations on the "Orient" with supporting institutions, infrastructures, vocabulary, scholarship, imaginary, doctrines, and even colonial bureaucracies. He explains that "Orientalism is a style of thought based upon an ontological and epistemological distinction between 'the Orient' and (most of the time) 'the occident"' (Said, 1979, p. 2). In a later article, Said (1980) writes of a lack of effort on the part of the "Orient" to counter the hegemonic narratives:

To dispel the myths and stereotypes of Orientalism, the world as a whole has to be given an opportunity to see Moslems and Orientals producing a different form of history, a new 
kind of sociology, a new cultural awareness: in short, the relatively modest goal of writing a new form of history. (para. 16)

Like Said, I deeply believe that as Arabs, we can only dispel dominant misrepresentations by "writing" a different form of history, and that we must do this in our own words. Our own voices and our own narratives must tell our stories and speak about our own cultures and religions. We must counter what Antoine calls "a politics of the herds." Indeed, we must do it for ourselves. Frantz Fanon (2008) states: "When I should have been begged, implored, I was denied the slightest recognition? I resolved, since it was impossible for me to get away from an inborn complex, to assert myself as a BLACK MAN. Since the other hesitated to recognize me, there remained only one solution: to make myself known" (p. 87, my emphasis).

Whether as black men and women, as Arab men and women, as Muslims/non-Muslims, as marginalized and as Othered, making ourselves known and asserting ourselves is how I believe that we may open spaces for other ways of knowing. To let ourselves be known is also to let our story be known, our lived experience be known and, most importantly, to be told by us. I will not sit back and bewail Western hostility, but I will continue to look for ways to trigger cultural awareness and an empathetic cultural understanding, and to take part in "writing a new form of history."

In an attempt to assert his Arab Muslim identity, Adam proudly makes known his principles as an Arab-Muslim. He tells of how as an Arab and as part of his Arab values, he will "serve" Canada as it has served him and will "defend" it as he would his own homeland of Syria. He is grateful for the opportunities that are now available for his children who, he believes, might have been part of a lost generation otherwise. "Canada is in our heart," he expresses. Adam also makes known his beliefs and values as an Arab-Muslim through reciting Prophet Muhammad and the Koran and says,

[Reciting the Prophet Muhammad] "There is no difference between an Arab or Ajami (non-Arab), or for a non-Arab over an Arab. Neither is the white superior over the black, nor is the lack superior over the white - except by piety"... and [quoting Surah Al-Hujurat 49:13, Al-Qur'an al-Kareem] 'O mankind! We created you from a single (pair) of a male and a female, and made you into nations and tribes, that ye may know each other not that ye may despise (each other). Verily the most honoured of you in the sight of Allah is (he who is) the most righteous of you."

Adam ties his religious practices to his life in Canada and explains that it is his duty as a Muslim following God's command to take care of his neighbors. He explains, "When your neighbor is well, then you are well." Here, I deeply believe that what is needed for an empathetic cultural understanding, "a cultural verstehen," to emerge are the voices of the likes of Adam to make known their stories, their principles, and their foundations as humans in one humanity.

Furthermore, Daniel speaks to the dangerous role that the media plays within this context, and of its hegemonic influences on people's ideologies and ways of thinking. He speaks to how he believes the media "steers" the masses in one direction, transforming normal cultural practices into extremes. He points to the fact that the world seems to divide and designate us according to our nationalities, where we, as Arabs, have become identified to some as "terrorists," and how with a "piece of paper" (referring to a Canadian Permanent Residence Card and passport), we 
become "first-class citizen[s]." He is cynical and poignant in his reflections. He suggests that it is our "lived experience" that should define our story. As Daniel spoke, I was very moved. I nodded my head in approval. I thought of my own story as a Syrian woman judged on the basis of my nationality.

As an act of resistance, I once wrote a letter to U.S. Border and Security Facilitation published in The Daily Townsman in Cranbrook, BC where I once lived (Alatrash, 2009). In my letter, I recounted one of the most humiliating and degrading experiences I had lived as an ArabSyrian woman in the West, and I documented how I was searched and stripped of my dignity by a U.S. Border and Security officer simply because of the Syrian passport I held (see the Appendix for the extract from the letter). Perhaps, the letter did not make a difference back then; however, for me this letter was my expression of resistance and it was my way of exercising of democratic rights and agency. It was my way of making myself known, of asserting myself.

Years after this incident, I wrote the story of Um Maryam in my collection of short stories: "Stripped to the Bone". In this story, Um Maryam, a Syrian woman from Aleppo is forced to seek refuge in the U.S. along with her husband. In the critical incident, Um Maryam is carrying a bag of herbs that she picked, not only with her hands but also with her heart, from her garden in Aleppo. At the airport, the American immigration/customs officer informed her and her husband that no herbs are allowed into the U.S., and that "these are the rules...this is the law" (Alatrash, 2016, pp. 133-134). Um Maryam pleaded. She turned to Abu Maryam (her husband), in Arabic and said, "Tell him that they are the only piece of our homeland that I brought with me. Tell him that they are its smell and taste, and I can't find this anywhere in the U.S." (p. 134). The officer (as I had often also witnessed in my own journeys to the U.S.) seemed rigid and unbending. I recall how when I was writing this story, that the power was in my handthat I had the choice of either moving the officer's hands to throw away the herbs or of moving his heart closer to feel Um Maryam's pain. Um Maryam was desperate and so she resorted to her broken English and begged:

"For Jesus, the Son of God [she was Syrian-Christian], let me. Please. I always pray for you. Please I may no visit my home country again, please. I have no home now. My home destroyed, my garden destroyed, my heart destroyed. I pray for your homeland America. I will plant this is in my garden in Texas, and you come and visit me anytime. Please." Her tears sprung from a burnt heart and they also burned the officer's heart. (p. 134)

Following Fanon's example, as I wrote the ending of Um Maryam's story, it was my chance to also write in a language of love. It was my chance to forgive the officer that had exercised his legal power over me at the border crossing. It was my chance to exercise a rhetoric of hope and possibilities. As a man who has lived and felt the deepest implications of colonial discourses, Fanon (2008) writes,

I [Frantz Fanon] am my own foundation. And it is by going beyond the historical, instrumental hypothesis that I will initiate the cycle of my freedom... That it be possible for me to discover and to love man, wherever he may be. (pp. 180-181)

To insist on the possibility and continuity of love within the most painful and suffocating of human conditions is, in my opinion, a most breathtaking manifestation of hope. Fanon's language embodies a language of hope and possibilities, and I too will insist on searching and 
finding the love that is bound to reside in every human heart. And so, I ended the story of Um Maryam with the following lines:

"Please, Ma'am [said the officer, in a Texan accent]. Stop Crying. I am very sorry for your pain," as he closed the passports, stamped the date of entry—January 23, 2014 —and said, "Welcome to the United States of America."

“Abous-rouhak,” Um Maryam cried.

Translation: Abous-rouhak is an endearing expression used especially in Aleppo. It is Arabic for "I am kissing your soul" (the female form is Abous-rouhik). (p. 134)

[The word is applied in the figurative sense of the meaning.]

\section{Conclusion}

In this essay, I have autoethnographically thought through issues of identity as they relate to the Syrian Diasporic realities. I have found that displaced Syrian peoples continue to look for ways to negotiate their differences within the context of their new Canadian homeland. They are cognizant that their identities are: continuously emerging and evolving, are not fixed in the past of a lost homeland, and furthermore, are fluid and actively 'becoming' within moments of continuity (Hall, 1994). I have also found that displaced Syrian newcomers face the Western media's knowledge concerning the Arab subject, one that is underpinned by colonial narratives and hegemonic discourses, and as a result, they have felt significantly different and Othered. I hope that this essay has added an empathetic understanding of the lived experiences of some of the Syrian Diasporic peoples. On this final note on empathy, and on hope and possibilities, I will leave my readers with the Arabic word for hope, a word that I will continue to think and write with-the Arabic word for hope is: Amal. 


\section{References}

Alatrash, G. (2009, January 23). Letter to U.S. Border and Security Facilitation. The Daily Townsman.

Alatrash, G. (2016). Stripped to the Bone: Portraits of Syrian Women. Ottawa, ON: Petra Books.

Alatrash, G. (2019). On the Lived Experience of the Syrian Diaspora in Canada. (Unpublished Doctoral Thesis), University of Calgary, Calgary.

Cabral, A. (1973). Return to the source. Selected speeches by Amilcar Cabral. Edited by Africa Information Service. New York; London: Monthly Review Press.

Chang, H. (2008). Autoethnography as method. Walnut Creek, Calif.: Left Coast; Oxford: Berg [distributor].

Du Bois, W. E. B. (2012). Striving of the negro people. The Atlantic.

Ellis, C. (1991). Sociological Introspection and Emotional Experience. Symbolic Interaction, $14(1), 23-50$.

Ellis, C. (2004). The ethnographic I: A methodological novel about autoethnography. Walnut Creek, CA: AltaMira Press.

Ellis, C., Adams, T. E., \& Bochner, A. P. (2011). Autoethnography: An overview. Forum: Qualitative Social Research, 12(1).

Fanon, F. (2008). Black skin, white masks: Pluto Press.

Gramsci, A. (1971). Selections from the prison notebooks of Antonio Gramsci (Q. Hoare \& G. N. Smith Eds.). N.Y.: International Pubs.

Hall, S. (1994). Cultural identity and diaspora. In P. Williams \& L. Chrisman (Eds.), Colonial discourse and post-colonial theory: A reader (pp. xii, 570). New York: Columbia University Press.

Lichtman, M. (2010). Qualitative research in education: A user's guide (2nd ed.). Thousand Oaks, Calif.: Sage Publications.

Moll, L., Amanti, C., Neff, D., \& Gonzales, N. (1992). Funds of knowledge for teaching: Using a qualitative approach to connect homes and classrooms. Theory Into Practice, 31(2), 132-141.

Said, E. (1979). Orientalism (1st Vintage Books ed.). New York: Vintage Books.

Said, E. (1980, April 26). Isalm through Western eyes. The Nation. Retrieved from: https://www.thenation.com/article/islam-through-western-eyes/

Said, E. (1999). Out of place: A memoir. New York: Knopf.

Said, E. (2002). Reflections on exile and other essays. Cambridge, Mass.: Harvard University Press.

Cultural and Pedagogical Inquiry, Summer 2020, 12(1), pp. 22-36

ISSN 1916-3460 @ 2020 University of Alberta

http://ejournals.library.ualberta.ca/index.php/cpi/index 
Simmons, M. (2012). Politics of Diaspora. ProQuest Dissertations and Theses, OISE/University of Toronto.

van Sluys, K., Lewison, M., \& Seely Flint, A. (2006). Researching Critical Literacy: A Critical Study of Analysis of Classroom Discourse. Journal of Literacy Research, 38(2), 197-233.

Yan, M. C., \& Anucha, U. (2017). Working with immigrants and refugees: Issues, theories, and approaches for social work and human service practice. Don Mills, Ontario, Canada: Oxford University Press.

\section{APPENDIX}

Below is an excerpt of a letter that I wrote on January 23, 2009 in The Daily Townsman (a newspaper based in Cranbrook, British Columbia). It highlights my inhuman experience as a Syrian citizen crossing one of the U.S. borders to Canada:

Dear Executive Director of Border and Security Facilitation of the United States of America,

...on my last exit from the Roosville/U.S. border in Montana on January 6, 2009...I was subjected to a degrading body search - I was ordered to pose with both hands spread apart on a metal bar, legs spread apart, body leaning forward, and tolerated the hands of the female officer as she scanned and violated every inch of my body, pressing wherever necessary in order to make certain that I did not carry weapons or whatever else she was searching for! It was indirectly explained that this degradation was inflicted upon me because of my Syrian passport. When I expressed the absurdity of the situation, I was asked verbally "not to flinch" and to cooperate with what was deemed U.S. law.

...Upon my return to Canada, I insisted on learning more about the legitimacy of your actions, and my research revealed the following:

As of September 12, 2002 (one year after the 9-11 terrorist bombing), the United States' Department of Justice declared a notice titled: Registration and Monitoring of Certain Non-immigrants from Designated Countries.

...I have learned that as a Syrian citizen, I am categorized under Call-in Group 1, as labeled by U.S. immigration. Other categories include: Afghanistan, Algeria, Bahrain, Bangladesh, Egypt, Eritrea, Indonesia, Iran, Iraq, Jordan, Kuwait, Lebanon, Libya, Morocco, North Korea, Oman, Pakistan, Qatar, Saudi Arabia, Somalia, Sudan, Syria, Tunisia, United Arab Emirates, and Yemen.

The war on terrorism, as explained by President Bush, is a war that was launched as a result of the 9-11 attacks. However, it is important to note that 15 of the 19 hijackers who were on the airplanes on September 11th were from Saudi Arabia. None were from the countries classified as Group 1 which include Iran, Iraq, Libya, Sudan or Syria.

According to Bush, my country is blamed for "harboring terrorism." Yet, dear Sir, I find it important to highlight that fact that my country has never been involved in any terrorist 
attacks on U.S. soil, whereas the opposite holds true in the case of the U.S., when on October 26, 2008, the U.S. Army carried out a preemptive raid inside a Syrian village near the Iraqi border, killing at least eight...

Dear Sir, my father who loved his country as much as you love yours, migrated to the United States of America in 1986, and left behind his beloved people, culture, language, and all that was loved by his 70-year-old broken heart. He sacrificed it all so that he could spare his family from undergoing biased discrimination and degradation - an expectation promised by your country's ideals and principles. Had my father been alive today, he would have shamed you for the way you disgraced his daughter in the name of your country!

I lived on your soil for twenty-plus years. My first high school homecoming, my first love, my first day in an American university, my brother's wedding, my father's funeral, my wedding, the birth of two of my children, my graduation from a Master's program... are all memories that I experienced while living on your soil. I would also like to add that I adhered legally to your immigration law for as long as I lived in the United States, a reason for not obtaining U.S. citizenship after 20 years of residence in your country.

My daughter and my son are American citizens, a privilege that I will teach them never to take for granted. My brother is a U.S. citizen and a Hematologist/Oncologist in one of your most reputable cancer centers, and he was one of the people whom, when one of the hurricanes hit Houston, took on the decision of remaining next to his patients' bedside (your fellow U.S. citizens) while his family evacuated the area...(Alatrash, 2009) 